\title{
APPLICATION OF UNMANNED FLYING VEHICLE FOR OBTAINING DIGITAL ORTHOFOTOMAPS
}

\author{
Pisetskaya Olga $^{1}$, Isayeva Yanina ${ }^{1}$, Goutsaki Maksim ${ }^{2}$ \\ ${ }^{1}$ Belarusian State Agricultural Academy \\ ${ }^{2}$ Republican agricultural aero-geodesic unitary enterprise BelPSHAGI, Belarus
}

\begin{abstract}
Nowadays, surveys using unmanned aerial vehicles is becoming popular. The resulting orthophotomap is the final product for creating digital plans and cardboard.

The objectives of the study are to study the possibilities of obtaining orthophotomaps from survey materials using unmanned aerial vehicles based on the results of the experiment.

The article describes various types of aerial photography. Some types of unmanned flying vehicles to conduct aerial photography for the purpose of monitoring, engineering surveys, inventory of agricultural land, and crop forecasts are considered. A description of aerial photography surveying is given on the example of the city of Dzerzhinsk, Minsk Region, which is performed taking into account the unmanned flying vehicles of GeoScan 201 and the Republican agricultural aero-geodesic unitary enterprise BelPSHAGI. A description of the GeoScan Planner software and basic pre-flight preparation is given. The stages of the preparatory work before the aerial photography, the creation of the planning and high-altitude geodetic justification, the implementation of aerial photography procedures, the steps of the aerial photograph anchorage procedure are considered. Agisoft Photoscan, which allows to get clouds of points, surfaces, 3D models and orthophotomaps using digital raster images are presented. The map of heights (DEM) of the terrain and the orthophotomap was made on the basis of a dense points cloud. According to the results of the research, a conclusion was made on the possibility of using aerial photography materials obtained using unmanned flying vehicles to get orthophotomaps of the required accuracy.

Key words: Unmanned Flying Vehicle, orthophotomap, photographs, Agisoft PhotoScan.
\end{abstract}

\section{Introduction}

Orthophotoplan is a photographic plan of the area on the accurate geodetic basis, obtained from aerial photography or aerospace survey, with the transformation of images by means of orthorectification.

Cartographic information for the construction of orthophotos is collected through aircraft measurements made with analog cameras, however, it's expensive. Another possibility is to use spacebased imagery, but the accuracy of coordinates obtained from these images is insufficient. Unmanned aerial vehicles provide images with sufficient accuracy of coordinate points, and the cost of aerial photography is reduced (Создание ортофотопланов, 2019).

Surveying with the use of unmanned flying vehicles is becoming increasingly popular. Digital orthophotomaps obtained as a result of unmanned aerial photography filled with vector data and linked to external databases are used as the final product in geographic information systems, as well as the planned background for creating digital topographic plans and cardboards. Unmanned flying vehicles provide images with sufficient accuracy of coordinate points, and in this case geometric accuracy of landscape elements on orthophotomaps should be very high according to the current regulatory documents. Aerial photographs from the unmanned flying vehicle GeoScan 201 were used to carry out experiments.

\section{Methodology of research methods and materials}

The research methods are the experiment to study the possibility of using materials from unmanned flying vehicles for creating digital models of landscape elements, and for building orthophotomaps. The main source materials are photogrammetric digital aerial photography 1: 2000 scale in Minsk region.

\section{The discussion of the results}

Aerial survey of the area for the purpose of creating and updating public topographic maps and plans is carried out in accordance with the long-term general mapping plan for the territory of the Republic of Belarus, which is approved by the State Property Committee of the Republic of Belarus and agreed upon with other involved government bodies in the prescribed manner (Общие технические условия...., 2008). 
Aerial surveys are made to create and update public topographic maps of 1:10 000 - 1: 100000 scales, state topographic plans of 1: 2000 - 1:10 000, 1:25 000 scales and are carried out by organizations of the State Committee on Property and the Ministry of Defense of the Republic of Belarus.

The dates and venue of aerial surveys are consistent with the Ministry of Defense of the Republic of Belarus and the Aviation Department of the Ministry of Transport and Communications of the Republic of Belarus in the prescribed manner.

If aerial surveys need to be performed for the territory adjacent to the State Border of the Republic of Belarus, it is additionally necessary to coordinate this work with the State Border Guard Committee of the Republic of Belarus, the Ministry of Foreign Affairs of the Republic of Belarus, the State Security Committee of the Republic of Belarus in the prescribed manner.

The object of aerial photography is areas of the earth's surface with defined boundaries indicated in the technical project for the production of aerial surveys.

For the purpose of creating and updating state topographic maps and plans, the following types of aerial photography are distinguished: areas; separate routes; frame route systems.

Aerial photography of the area is made with the purpose of obtaining materials for creating and updating public topographic maps and plans, creating special maps and photographic documents, as well as for drawing up and updating city plans.

Aerial photography of separate routes is carried out with the same purpose of obtaining materials on linear and small terrain objects: railways and highways, gas and oil pipelines, narrow land bands (border areas), small settlements, etc., when aerial photography is impractical.

Aerial photography of frame routes is carried out with the purpose of obtaining materials for creating a planned-high-altitude geodetic base necessary for the subsequent photogrammetric thickening of the network of reference points on the basis of aerial photography materials.

Accounting for the performance of aerial photography, verification of aerial photography materials in terms of completeness and quality, as well as the preparation of these materials for transmission in the prescribed manner to the State Cartographic and Geodesic Fund of the Republic of Belarus are carried out by organizations carrying out aerial survey in accordance with the requirements of technical regulatory legal acts.

Upon completion of the production of aerial surveys, the State Property Committee and the Ministry of Defense do not exceed 15 working days in accordance with the procedure established by the legislation, aimed at excluding images of special regime and regime objects from aerial photography (Общие технические условия...., 2008).

Unmanned flying vehicles are used for both civil and military purposes: for operational aerial photography, broadcasting, search and rescue, reconnaissance and surveillance, maintaining law and order, etc. Unmanned flying vehicles are of great variety, their design and size depend on the tasks intended.

In addition to topographical surveys, unmanned technologies are used for various forms of monitoring, the objects of which can be unauthorized dumps of solid household waste, linear objects such as power lines, pipelines and transport infrastructure. Also, an unmanned flying vehicle solves the problems of determining the volumes of earth masses and their dynamics in the development of open pit deposits and quarries. Compared to space monitoring, an unmanned aerial vehicle provides disproportionately more relevant information. The agricultural sector has recently become one of the main consumers of this technology. Agricultural holdings and large agricultural associations with large areas of undeveloped and open areas are interested not only in the production of engineering and geodesic surveys for the reconstruction and new construction, but also in monitoring and inventorying farmland, assessing crop germination, yield forecast, monitoring erosion processes (Технический кодекс установившейся ...., 2008).

An unmanned flying vehicle is an aircraft without a crew on board that uses the aerodynamic principle of creating lift using a fixed or rotating wing, equipped with an engine and having a payload and duration of flight sufficient to perform special tasks.

To perform aerial photography one unmanned flying vehicle is not enough. Aerial photography complex, which is a combination of an unmanned aerial vehicle, its instrumentation, payload and ground control station, is required.

The payload for aerial photography tasks is a digital camera, as an addition a video camera, a thermal imager, an infrared camera can be used.

Aerial photography from an unmanned flying vehicle with the installation of appropriate imaging equipment allows to get digital images of super high spatial resolution of up to $2 \mathrm{~cm}$. 
The ground control station performs the tracking flight, receiving data, transfer of control commands. Unmanned flying vehicles are distinguished by the method of control: manual control, automatic control, semi-automatic control.

It should be noted that ultralight unmanned flying vehicles do not allow equipping them with sophisticated high-precision imaging equipment, since they are significantly limited in payload weight. In addition, these devices are strongly influenced by weather conditions (Макаров, 2012).

The world has a large number of unmanned flying vehicles, differing in their specifications and characteristics.

In the Republic of Belarus, unmanned flying systems of the "mini" class are being developed with a range of 20 to $70 \mathrm{~km}$, which, depending on the target load, are capable of photo, video, infrared or multispectral imaging using optical systems installed on a gyro-stabilized platform, in the light and dark of a day. A large range of target load capabilities and high aerodynamic qualities of aircraft allow the use of unmanned flying vehicle "Busel" (Fig. 1), "Busel M" and "Busel M50" to detect emergencies, monitor the condition of areas with oil and gas pipelines, combating poaching, keeping animals in check, monitoring traffic flows on the roads, controlling the state border, monitoring the condition of power lines and agricultural land, etc.

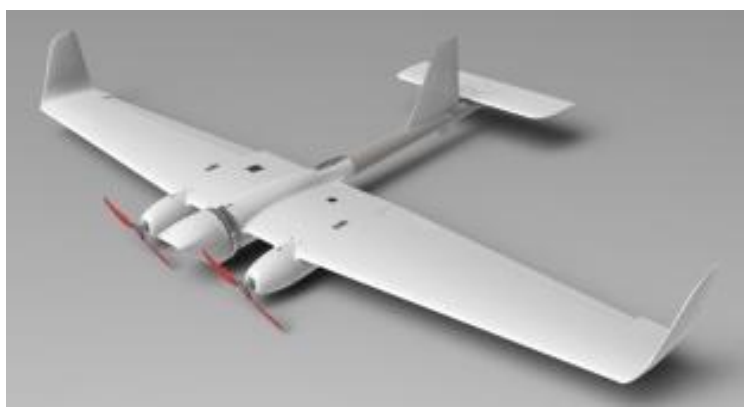

Fig. 1 Unmanned flying vehicle "Busel"

As the use of unmanned aerial vehicles (UAVs) has great potential to support and address some of the most pressing problems, many studies have been carried out in recent years reflecting the possibility of their usage in a great variety of contexts: in land mapping, vegetation state (Солоха, 2018), (Башилов и др., 2016), phenology and health, precision farming, monitoring crop growth, mapping soil surface characteristics (Петрушин и др., 2016).

Some authors analyzed the prospects of using UAVs in agriculture of Tatarstan for monitoring agricultural lands (Логинов и др., 2017), crops surveillance, and predicting crop yields. Still other articles are devoted to UAVs used for precision agriculture (Акинчин и др., 2017).

Within the land management and land cadaster there are also many possible applications of UAV. Descriptions are given of the UAVs use to create a topographic base with processing in photogrammetric software complexes for the purposes of agricultural production. (Линьков, 2018). A modern method for conducting land measurements from the air based on photoplans, the advantage of performing aerial photography using UAVs to obtain orthophotomaps with an accuracy of $3 \mathrm{~cm}$ in X, Y is described by several authors Galeev, Beloev (Галеев, 2016), (H. Beloev, 2016)

However, the analysis of the wide range of functionalities provided by UAVs is not sufficient without taking into account the factors that influence the quality of images. Although the issues of UAVs application have been covered sufficiently in literature, some methodological aspects still need to be studied. It is necessary to consider the technology for performing aerial photography and photogrammetric processing of the collected images to obtain high-resolution images of orthophotomaps for land management purposes which is particularly valuable in the case of remote sensing images.

The subject of the footage was the city of Dzerzhinsk, Minsk region. At the footage site, in the field, the coordinates of the markings were determined using GNSS. The number and location of the vertical planning identification is determined by the project.

After obtaining the coordinates of the points of identification marks, using the GeoScan201 unmanned flying vehicle was used for surveying the terrain.

The unmanned flying vehicle GeoScan 201 (Fig. 2) is intended: to obtain geolocated images of objects and areal footage, with subsequent processing of photographic material; for creating orthophotomaps of maps of scale 1: 500, 1: 2000; creating a terrain model in 3D; creating maps of terrain heights; 
calculating the volume of rocks in quarries and bulk objects (Руководство по эксплуатации БПЛА, 2019).

The GeoScan 201 UAV has the payload of $7.6 \mathrm{~kg}$, a wingspan of $2225 \mathrm{~mm}$, a side length of $710 \mathrm{~mm}$, a flight duration of up to 150 minutes at the speed of $17-27 \mathrm{~m} / \mathrm{s}$ and a maximum flight altitude of 1000 $\mathrm{m}$.

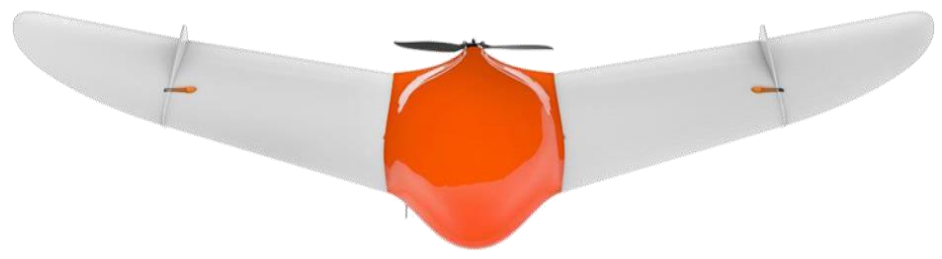

Fig. 2. GeoScan 201 unmanned flying vehicle

The flight software is GeoScan Planner, which is designed for: designing a flight task; passing prelaunch; control of the flight task; geolocation footage (Руководство по использованию оператора, 2019).

A fragment of an interactive map, which is used for design, is presented in Figure 3.

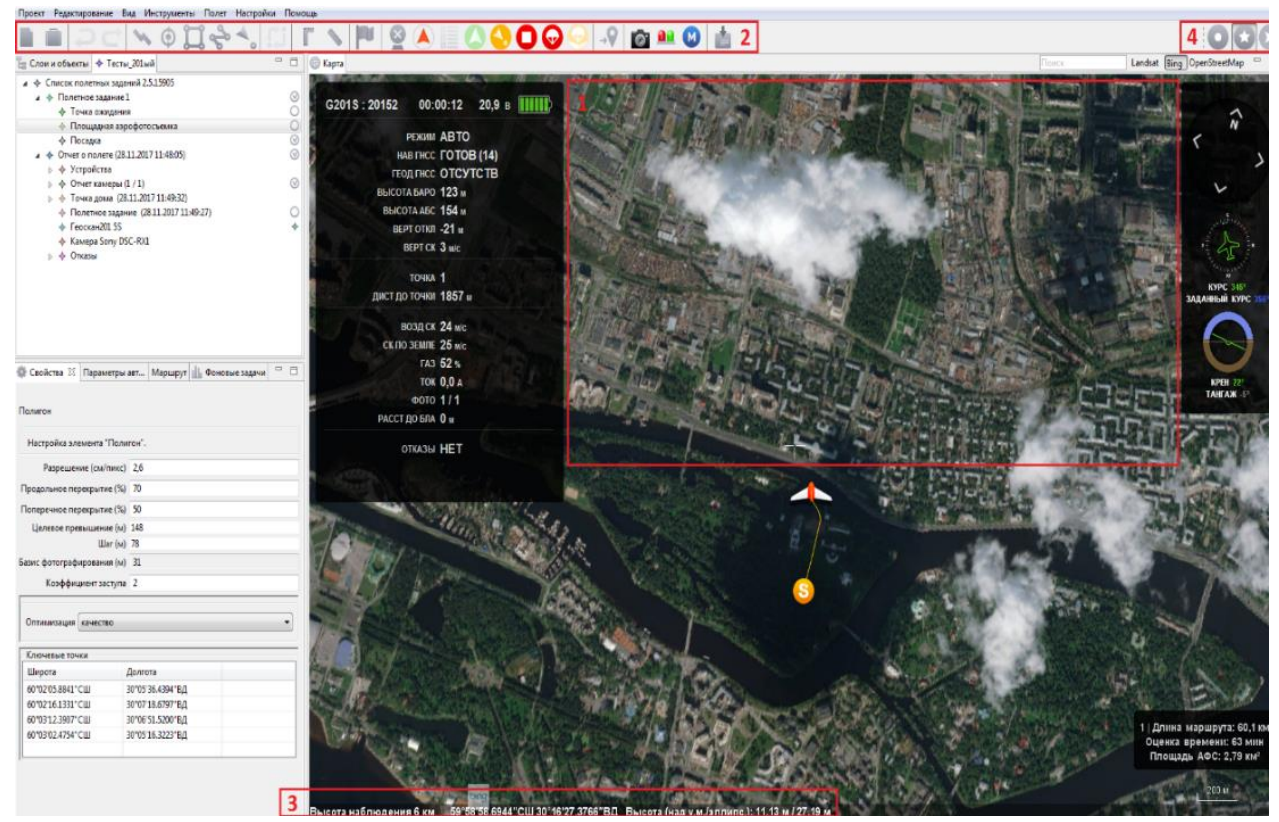

Fig. 3 Displaying an interactive map in Geoscan Planner

The Geoscan Planner program uses several ground data sources as a base map: Landsat, OpenStreetMap or Bing.

To compile a correct flight task, it is necessary to load the entire territory of the intended flight, preferably in maximum detail.

The GeoScan aircraft-type complex provides: areal photography according to a pre-compiled flight task, linear aerial photography based on a pre-compiled flight task, a flight along a predetermined trajectory at specified heights, a waiting point with wind measurement, flight on demand, remote control.

The Geoscan Planner program automatically saves the flight mission project in the computer's memory for future use. This allows to develop a project in advance, before going to the work site. It is enough for the operator to create a polygon directly along the boundaries of the studied area, the program will independently increase the length of the fly lines and their number in accordance with the surveying conditions.

When building a route, the climb and descent of an unmanned flying vehicle in the form of cylinders are displayed if the height difference of neighboring points is at least 30 meters (Fig.4; Fig.5). 


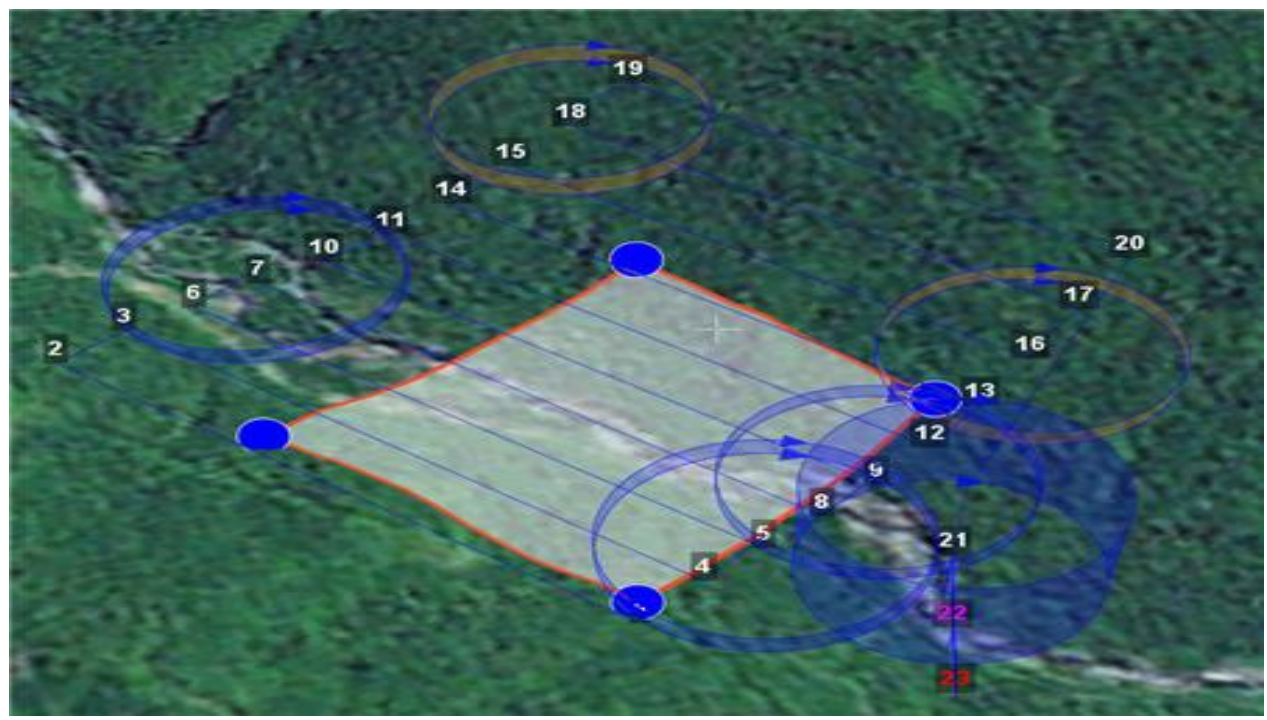

Fig. 4 Accumulation and Drop Cylinders

If the unmanned flying vehicle is gaining height, the cylinder is filled with orange, otherwise it is blue. To perform direct aerial photography from an unmanned flying vehicle, it is necessary to carry out a set of pre-flight operations in advance, including: a desk study of the shooting area and planning a shooting route; departure to the study area; deployment of an unmanned flying vehicle complex; the implementation of pre-flight checks and tests.

The actual preparation of the flight task is carried out on a laptop that is a part of the ground control station, where the supplier installs the Geoscan Planner software. This flight planning software product allows you to create various projects for shooting routes that are transmitted to an unmanned flying vehicle using radio signals. In addition, it is possible to establish shooting parameters such as flight altitude, longitudinal and transverse overlaps, shooting steps, and others, all of which are interrelated, i.e. changing one of the parameters automatically changes the rest. Next, the program automatically builds the most rational shooting route, taking into account the formation of a certain stock of personnel at the edges of the section to be removed, while the operator has the ability to edit the vertices of the polygon after construction, thereby changing the route.

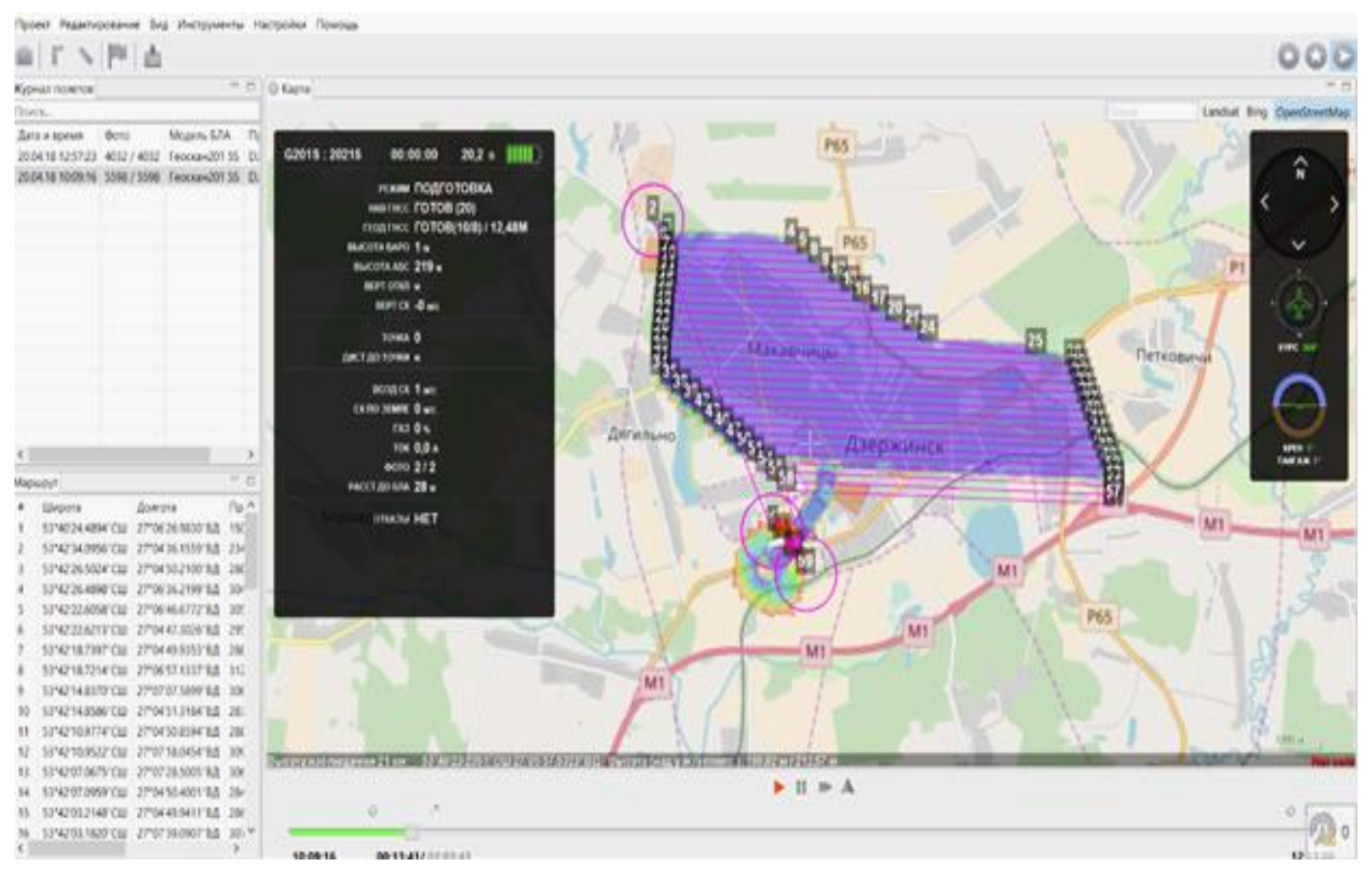

Fig. 5 Creating a flight task in GeoScan Planner software 
Having completed the formation of the flight task, a departure to the territory of the survey can be carried out.

Upon arrival, the deployment process of the unmanned flying vehicle complex takes place. As a payload on the unmanned flying vehicle GeoScan 201 can be used 2 types of camera. The first of them - Sony DSC-RX1 - has a high-resolution matrix of 24.7 megapixels.

The resolution of digital camera is $5.1 \mathrm{~cm} /$ pix, the focal length is $35 \mathrm{~mm}$. The average errors of determining photographing centers were calculated, which were $X=2.2 \mathrm{~cm}, \mathrm{Y}=5.5 \mathrm{~cm}, \mathrm{Z}=1.4 \mathrm{~cm}$. The average photographing altitude was $297.5 \mathrm{~m}$.

After the deployment of the ground control station, the Geoscan Planner software is launched, where the operator will have to indicate the landing point of the unmanned flying vehicle, taking into account the conditions of the terrain to be removed. After the creation of the landing route, a complex of works on prelaunch preparation is performed.

Aerial photography from an unmanned flying vehicle, as well as other types of topographic surveys, requires the creation of a planning and height-altitude geodetic justification. Therefore, the process of flight survey work is preceded by a complex of ground-based geodetic measurements.

The number of marks depends on the scale of the shooting. When shooting at a scale of 1: 2000 and 1: 5000 , the identifications are placed in rows across the aerial survey routes. Further, when linking aerial photography materials from an unmanned flying vehicle, these points are used as a geodetic basis for the formation of seamless mosaics, stereo pairs of images and other products. During the flight, the operator is obliged to monitor the climb and the overall stability of the device. The data for the binding is transmitted during the flight by the radio modem, and is recorded by the Geoscan Planner program. If the route is successfully completed by an unmanned flying vehicle, it will drop a parachute and land on reaching the landing point.

To get the binding files, you must save the data to the same folder where the snapshots were saved. The result of the work is a folder with snapshots and a data file of their binding, which can be used for further processing in the PhotoScan software or other software. After completion of shooting, it is recommended to conduct quality control of the aerial survey materials obtained. Next, you need to perform the binding procedure, which consists of several stages: the calculation of the coordinates of the centers of photographing; calculation of coordinates of marks; phototriangulation development.

The main process of processing aerial photography materials from an unmanned flying vehicle is carried out in Agisoft Photoscan software. This software product of automated photogrammetric processing of aerial photography data allows to obtain clouds of points, surfaces, 3D models and orthophotomaps using digital raster images, coordinates of photographing centers, materials for calibrating optical systems of cameras, coordinates of reference points on the ground, and control linear measurements on the subject .

Agisoft PhotoScan software is able to independently determine the position of cameras and build a sparse cloud of points on the basis of images, while it is possible to specify alignment parameters, such as alignment accuracy, the maximum number of points, the maximum number of projections. According to the results of the development of phototriangulation software Agisoft Photoscan allows you to create a large number of diverse products, including orthophotomaps terrain. Based on the camera positions calculated from the results of triangulation, the program calculates depth maps for each camera and builds a dense points cloud (Fig. 6).

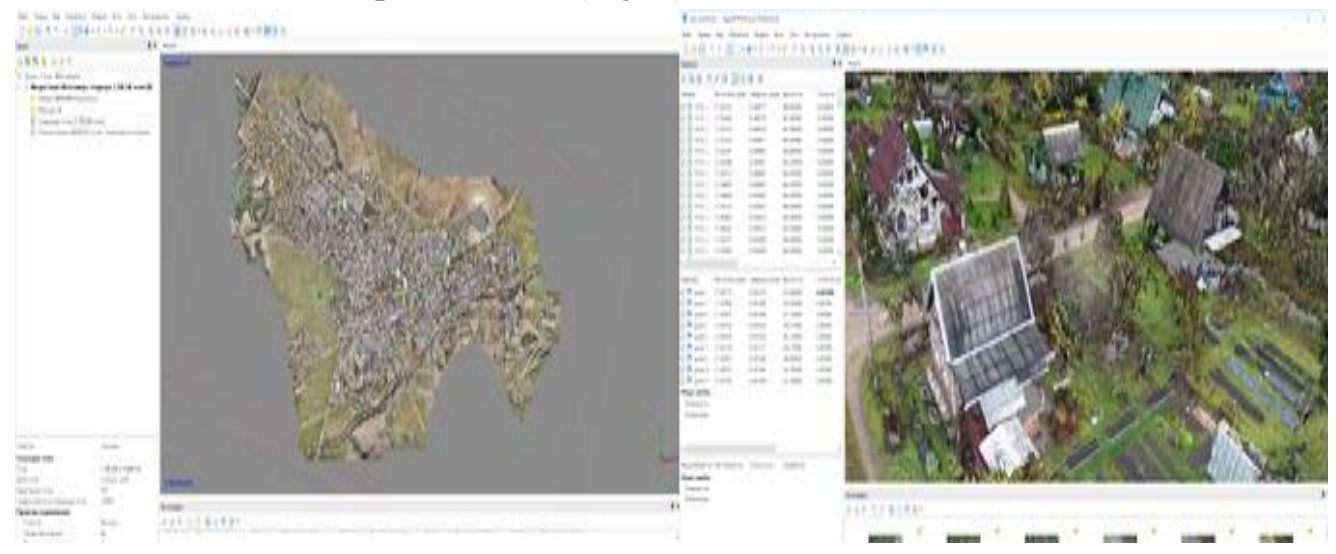

Fig. 6 A dense points cloud, built on the basis of aerial photography using unmanned flying vehicle 
Based on a dense points cloud, a map of the heights of the terrain can be constructed (Fig. 7).

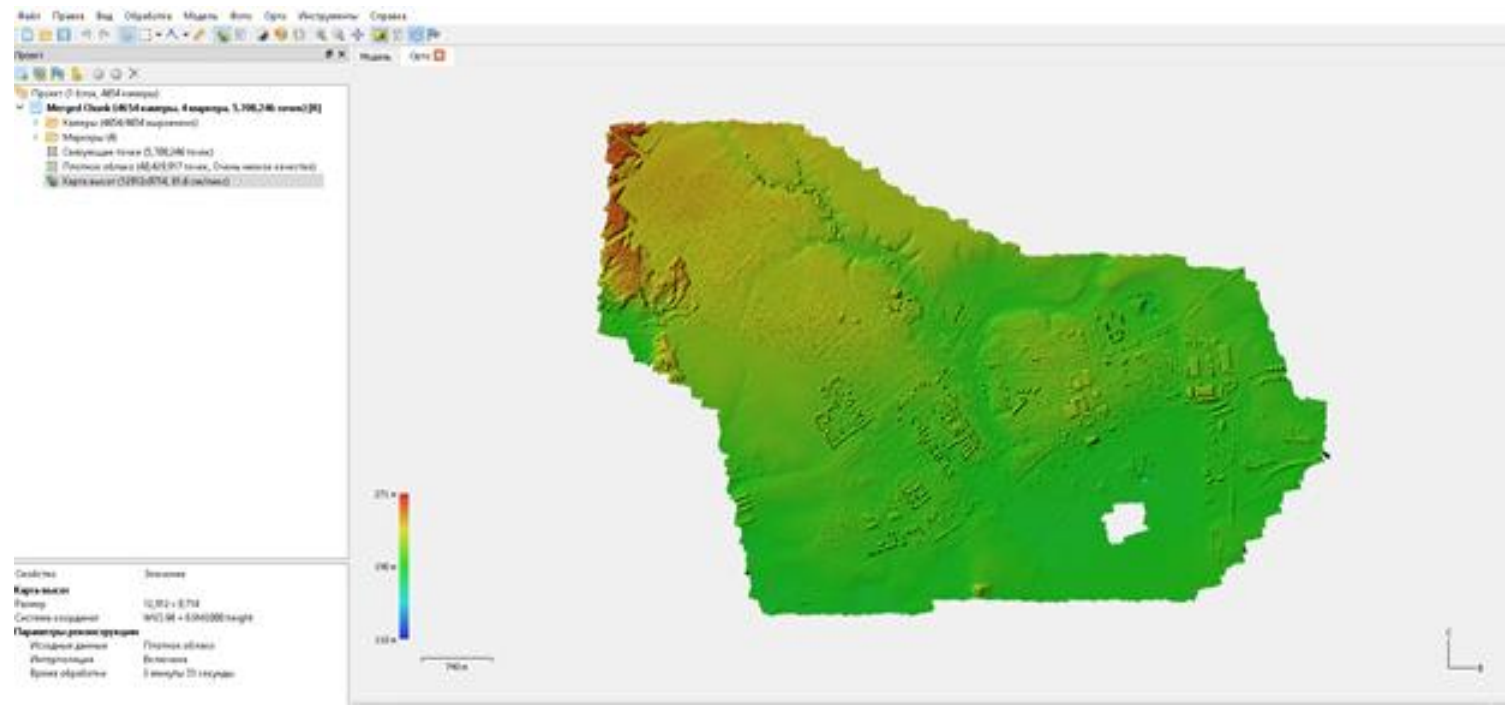

Fig. 7 Map of heights, built on the materials of aerial photography unmanned flyingl vehicle

The coordinate system must match the one used to snap the model. Changing the coordinate system is possible at a later stage of export.

Next is the direct construction of the orthophotomap (Fig. 8).

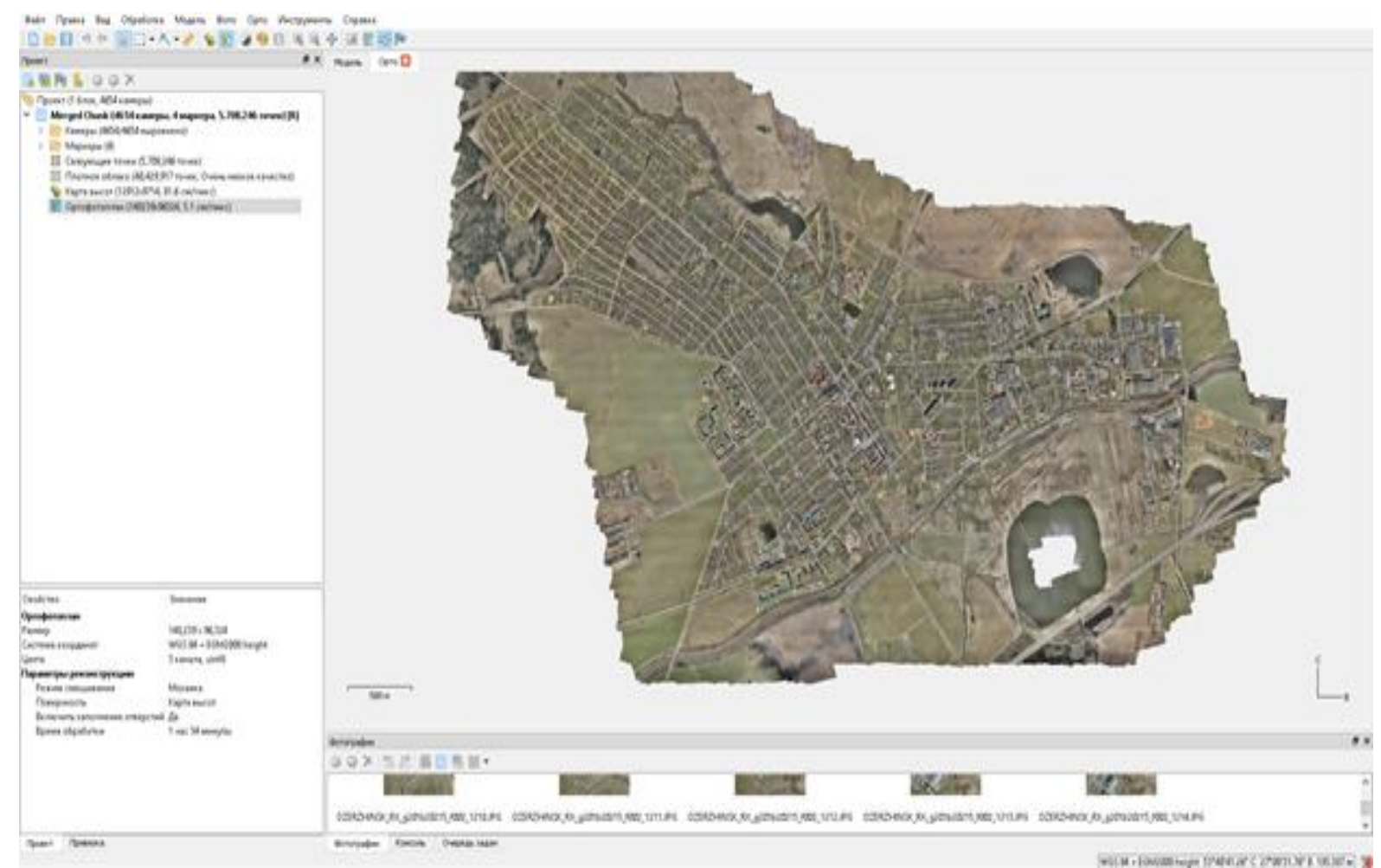




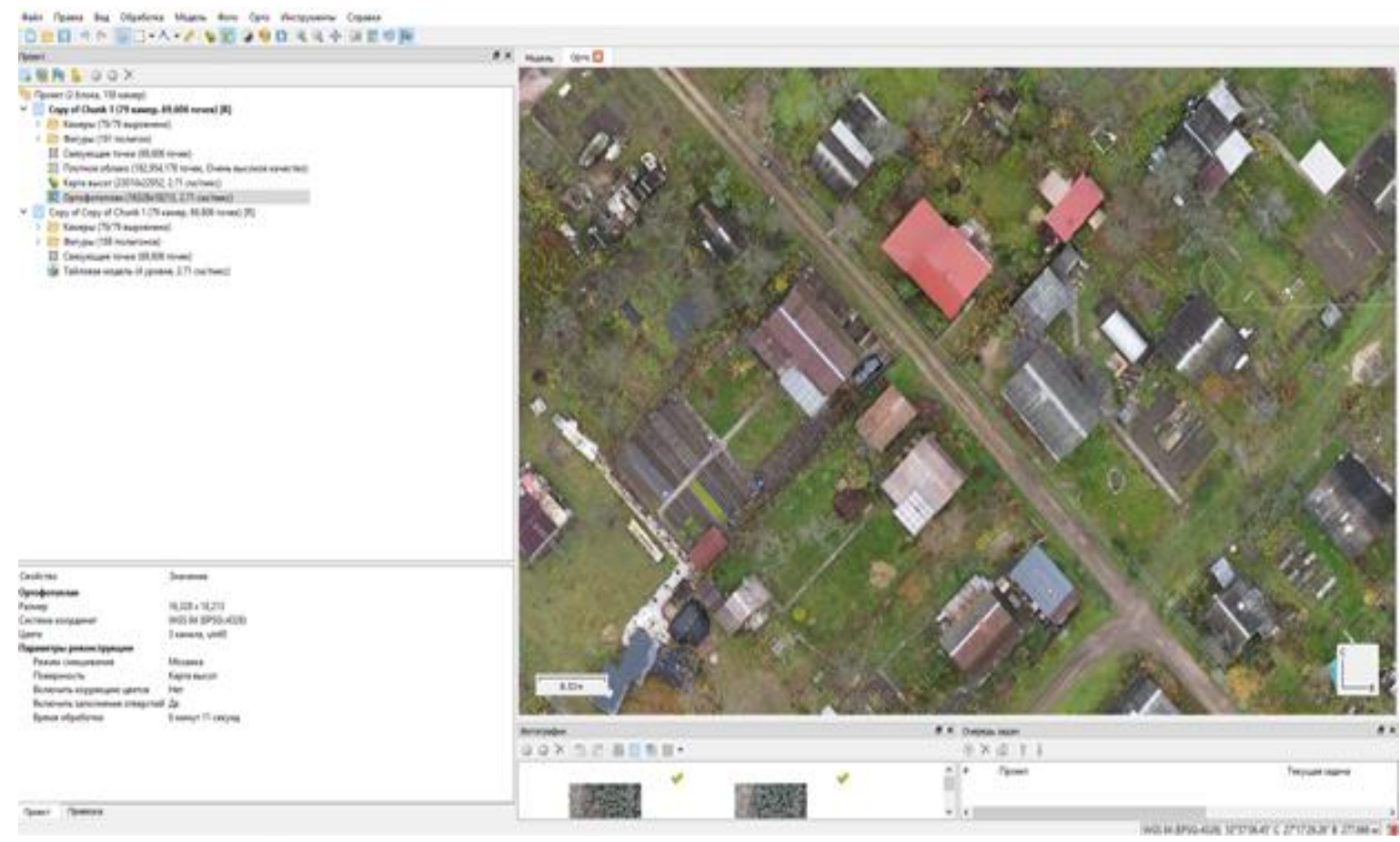

b)

Fig. 8 Orthophotomap compiled from materials of shooting using an unmanned flying vehicle: $\mathrm{a}$ - general view, $\mathrm{b}$ - enlarged view

When compiling an orthophotomap, Agisoft Photoscan builds cuts on its own, which can be edited if necessary (Figure 9).

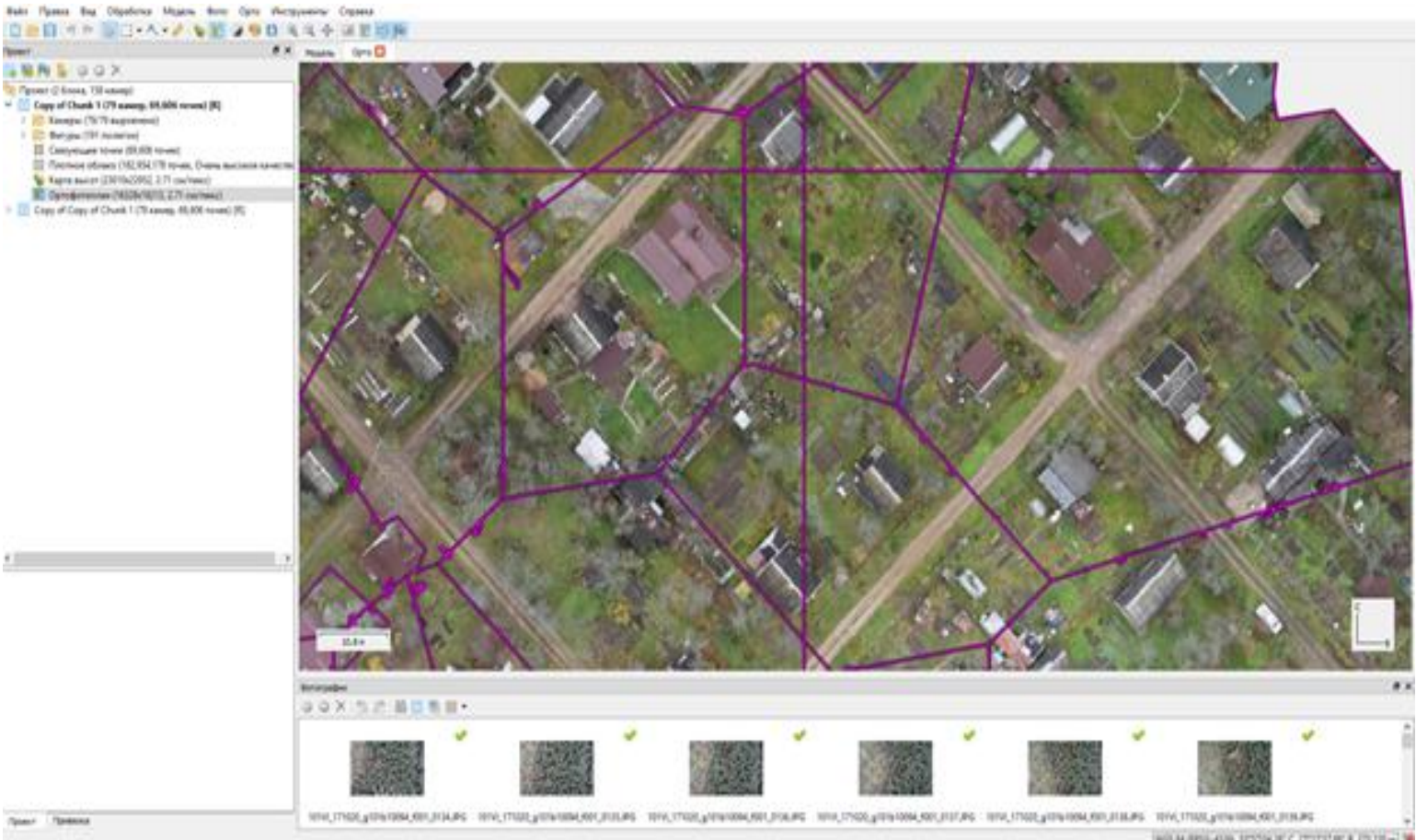

Fig. 9 Automatic construction of cutlines

According to the results of the construction of the orthophotomap, the standard quadratic errors were obtained for the control points $\mathrm{X}=1.2 \mathrm{~cm}$, for $\mathrm{Y}=1.8 \mathrm{~cm}$, for $\mathrm{Z}=3.0 \mathrm{~cm}$.

Digital terrain model editing and vectorization of structural elements of the relief and structures is carried out in stereoscopic mode in the Trimble Inpho software. Using an edited digital elevation model (or terrain), orthotransformation of aerial photographs will subsequently be carried out (Руководство по использованию оператора, 2019). 


\section{Conclusion}

1. An experiment has shown that aerial photography from an unmanned flying vehicle can successfully replace traditional aerial photography and ground-based methods of collecting spatial data in order to create topographic plans and large-scale maps. The accuracy of orthophotomaps created as a result of processing of aerial photography materials using an unmanned flying vehicle is not inferior to the accuracy of materials of traditional methods, which require a significant investment of time and money.

2. The present study has shown that it is necessary to do more research of the methodology of orthophotomaps construction produced from airborne photogrammetry to meet accuracy.

3. According to the described technology of performing aerial photography and the construction of the orthophotomap and its accuracy, it can be noted that the use of UAVs is economically advantageous.

\section{References}

6. H. Beloev, I. (2016). A Review on Current and Emerging Application Possibilities for Unmanned Aerial Vehicles. Journal Acta Technologica Agriculturae, Volume 19, Issue 3, pp. 70-76.

7. Акинчин, А., Левшаков, Л., Линков, С., Ким, В., Горбунов, В. Информационные технологии в системе точного земледелия (Information technology in precision agriculture). Вестник Курской государственной сельскохозяйственной академии, -2017. № 9. С. 16-22. (in Russian)

8. Башилов, А., Королев В., Можаев, К. Перспективы использования дронов в реализациях новейших агротехнологий (The prospect of using drones in the implementations of the latest agricultural technologies). Вестник ВИЭСХ, -2016. № 4(25). С. 68-75. (in Russian)

9. Галеев, Э. Применение беспилотных летательных аппаратов в землеустройстве и в кадастровой деятельности (The use of Unmanned Aerial Vehicles in land management and cadastral activities). Аграрная наука в инновационном развитии АПК: Междунар. науч-практ. конф., 2016.- С. 281-285.(in Russian)

10. Линков, А., Акинчин, А., Мелентьев, Н., Чупрынина, Н., Кузнецова, А. Применение ГИС-технологий в сельскохозяйственном производстве (The application of GIS technologies in agricultural production), Инновации в АПК: проблемы и перспективы -2018. № 1 (17). C. 118-125. (in Russian)

11. Логинов, Н., Сулейманов, С. Перспектива использования дистанционного зондирования Земли и БПЛА в сельском хозяйстве Татарстана (Perspective of use of remote sensing of the Earth and Unmanned Aerial Vehicles in the agriculture of Tatarstan). Вестник Казанского ГАУ,-2017. № 4(46). С.17-19.(in Russian)

12. Макаров, В., Бондаренко, Д., Макаров, И., Шрайнер, К. Опыт применения технологии аэрофотосъёмочных работ с беспилотных летательных аппаратов в горном деле (Experience in the use of technology of aerial photography with unmanned flying vehicles in mining). Золото и технологии,-2012. -№1. C.15.(in Russian)

13. Общие технические условия. Государственные топографические карты и планы. Ортофотопланы (General specifications. State topographic maps and plans. Orthophotomaps). 2008. СТБ 1892-2008. Введ.28.06.08. Постановлением №36 Госстандарта Республики Беларусь - 12c. (in Russian)

14. Основные положения. Государственные топографические карты и планы. Аэросъемка для создания и обновления государственных топографических карт и планов (Fundamentals. State topographic maps and plans. Aerial survey for creation and updating of state topographic maps and plans).2008. СТБ 19142008. - Введ. 31.10.08. Постановлением №53 Госстандарта Республики Беларусь - 17c. (in Russian)

15. Петрушин, А., Митрофанов, Е. Опыт использования БПЛА для мониторинга состояния сельскохозяйственных земель (Experience of use of Unmanned Aerial Vehicles for monitoring the state of agricultural land) Применение средств ДЗЗ в сельском хозяйстве: Междунар. науч-практ. конф., 2016.C. 81-84.(in Russian)

16. Руководство по эксплуатации БПЛА (The user manual for the UFV). Viewed 7 January, 2019 https://www.geoscan.aero/ru/products/geoscan201/agro (in Russian)

17. Руководство по использованию оператора (Operator's manual). Viewed 7 January, 2019 https://www.geoscan.aero/ru/products/geoscan201/agro (in Russian)

18. Создание ортофотопланов (The creation of orthophotomaps) Viewed 1 May, 2019 https://skb25.com.ua/services/geodeziya/sozdanie-ortofotoplanov (in Russian)

19. Солоха, М. Определение агрохимических показателей почвы на основе аэрофотосъемки с беспилотного летательного аппарата (Determination agrochemical soil indicators based on UAV aerofoto). Почвоведение и агрохимия, -2018. № 1(60). С. 67-76. (in Russian)

20. Технический кодекс установившейся практики. Государственные топографические карты и планы. Порядок создания ортофотопланов (Technical code of practice. State topographic maps and plans. How to create orthophotos).2008. - Введ. 01.02.2008. Белорус. гос. ин-т стандартизации и сертификации 9c. (in Russian) 
Information about authors:

Olga Pisetskaya, PhD, Dean of the Faculty of Land Management, Belarusian State Agricultural Academy, Republic of Belarus, Leninsky Boulevard, 4, Gorki, Mogilev region, +375-22-33-79644, e-mail: piseckaja@tut.by. Geodesy

Yanina Isayeva, MS, Chief lecturer of the Faculty of Land Management, Belarusian State Agricultural Academy, Republic of Belarus, Leninsky Boulevard, 4, Gorki, Mogilev region, +375-22-33-79656, e-mail: ianinaisaeva88@gmail.com. Geodesy

Maksim Goutsaki, Process Engineer, Republican agricultural aero-geodesic unitary enterprise BelPSHAGI, Republic of Belarus, Miru St., 1a, Priluki, Minsk region, +375-29-621-42-45, e-mail: max_gutsaki@mail.ru 